Colloquia Litteraria

UKSW

$2 / 2015$

MAŁGORZATA ŁUKASZUK

\title{
POWAGA KANONU I PROPOZYCJA Z DYSTANSU (TERESA FERENC)*
}

1.

Pisząc dziś o kanonie polskiej literatury XX-XXI wieku i widząc w nim miejsce także dla poezji Teresy Ferenc, nie sięgnę po stare definicje i nie pójdę wciąż wydeptywaną ścieżką ich rewizji i rewitalizacji. Nie będę nowoczesna, bo nie zignoruję wartości i tradycji. Czy będę zachowawcza, skoro nie docenię smaku modernistycznych pęknięć strategii szokowania? Chcę poszerzyć pojęcie kanonu o postawę, którą nazywam intencją afirmacji i uwiarygodnienia, a która "polega” na wyborze rzeczy ważniejszych (kulturowo, literacko, poetycko, egzystencjalnie wreszcie) spośród rzeczy współcześnie ważnych. Nie cenię więc niektórych dzisiejszych metodologii, bo lekceważą to, co stanowi istotę dzieła sztuki, papierową publicystykę i sieciową ramotę zrównują z literaturą, mnie zaś, jako czytelnika szukającego „powagi scalenia”, chcą ośmieszyć, osłabić, pominąć.

Wiem, że o kanoniczności dzieła współstanowią różne i często skonfliktowane aspekty i siły. Ale skoro nie ma żadnego powodu, by którąkolwiek z nich dziś wykluczyć - nadal, jak sądzę, jest w pojęciu kanonu miejsce na „relikt autorski”, decyzyjny i intencyjny. Nie mam tu na myśli ani naiwnych okoliczności biografii, ani irytującej pychy twórcy, lecz uprzedniość autorskiej intencji „bycia autorem” (pisarzem i poetą), lokującą się nie tylko wobec mód i zachłyśnięć, z jakimi do

* Szkic jest rozwinięciem wstępu, którym poprzedzam przygotowywany wybór poezji Teresy Ferenc (Oficyna Wydawnicza Volumen). 
utworu przychodzi nowoczesny czytelnik, ale także wobec pewnej stabilnej normy, która piszących (nawet skandalistów, barbarzyńców, banalistów) ogranicza, choć na tak wiele im pozwala.

Wiem, że jesteśmy w wielkim kryzysie, mogę nawet sporządzić solidny przypis do autorytetów „od” nud, rozproszeń, migotliwości, rozpołowień, mimów itd. Jednak nie stało się w świecie i kulturze nic, co sprawiłoby, że autor - i tylko on! - ma na serio znieważać sens kultury, literatury, a w niej poezji, skoro podjął decyzję o byciu autorem, zwłaszcza poetą. Może być zniesmaczony czy obolały, może głosić kres świata i sztuki, może być knajacki lub komiksowy, ba może być truchłem po własnej śmierci (wszak umarł...), jednak gdy zapisuje słowo-znak i ujawnia je jako przekaz, to opowiada w poemacie mit, rozpisuje na wersy świat, przełamuje konwencję asonansem i amorfizmem. Jest autorem i staje wobec nie-autora czy współ-autora, zawierając z nim (czytelnikiem, widzem, słuchaczem) umowę. Bierze na siebie szczególną odpowiedzialność nie tylko za uruchomienie dyskursu, ale i za emocje ewokacji, prawdziwość referencji, uczciwość wyobraźni. Będzie, nawet najbardziej sponiewierany i wyszydzony, wybrańcem i mędrcem wśród cichych, niemych, ślepych. I nikt, żaden natchniony postinterpretator, nie zwolni go z tego obowiązku.

No tak, już kilkaset razy odmieniał się język poezji i klasyczna gatunkowość, tyle już razy fundowaliśmy sobie i światu nową skalę zła - kanon wszakże świetnie dawał sobie radę i z barbarzyństwem, i z nudą, i ze szczurzym bohaterem. Po prostu musiał wchłonąć nasze banalne i straszne sprawy, pielęgnować i namaszczać kolejne nasze afekty i defekty. Pozostawiał w swojej domenie te, które zweryfikował czas, a więc następcy. Czytelnicy? Raczej ponownie autorzy, którzy czujności poznawczej poprzedników składają hołd nie tylko odą, ale i pastiszem, choć często miernym. Trwała i cenna okazała się w sztuce nie koncepcja piękna/dobra/wzniosłości/prostoty, lecz szczególna powaga „kaznodziejstwa” i „pedagogiki”, których nie ważmy się, proszę, sprowadzać do polityczno-socjologicznego rządu dusz. Świadomie nazywam autora - niech będzie to Sebyła, Bursa, Honet czy Tkaczyszyn - kaznodzieją i pedagogiem; wybieram dla nich te role tym konsekwentniej, im głośniej każe mi się dziś zrównywać 
bełkot z przekazem, tożsamość rozmieniać na mitologie nowoczesności, dekonstruować humanistykę i rozsmakowywać się tym, co za ogrodzeniem, w szafie, w kolonii i zwierzęciu.

Ktoś powie, że uśmiercony przez modernizm autor powraca u „starego poety". Ja powiem, że nigdy nie odszedł. Bo gdzie i dlaczego miał abdykować, skoro ma wolę stukać w klawisze? I powtarzam, że zawiódł czytelnik, w tym ponoć profesjonalny, gdy na światło sztuki wywiódł promocję towarzyską; z Rilkego, Mallarmégo, Friedricha czy Wittgensteina wysnuwał niezapisane przez nich, ale „dziś słuszne” światopoglądowo tezy, a w Krynickiego czy Białoszewskiego wmuszał słowa, których nigdy nie wypowiedzieli, nie zapisali.

Kanon tworzy powaga i wymaga on powagi. Nie chodzi mi oczywiście o powagę dostojeństwa czy retoryki, o rozstrzyganie wartości wedle zatwierdzonego wzorca religijnego, moralnego, estetycznego. Pisząc o powadze, piszę o poważnych skutkach działań, jakie podjął autor w chwili, gdy z kostiumów wybrał ten jeden, szczególny, opajęczony d a le ki mi k on te k s t a mi. Piszę o powadze wyboru - o decyzji opowiedzenia rzeczy ważniejszych spośród ważnych.

Niewiele mnie więc obchodzą autorskie pozy i gry, dające zapewne niebagatelne korzyści i niestety dozwolone w globalnej sieci. Nie będę łamać rąk i pióra nad możliwościami technicznymi współczesności, skoro sama z nich jakoś, nieporadnie, korzystam. Idę jednak, jako czytelnik, dalej. I czekam. Czekam, aż autor i jego krytyk się opamiętają, staną i obejrzą za siebie; i zobaczą "coś” nadal ważnego w tym, co upublicznili. Po pierwsze czekam więc na chwilę, gdy modny autor zechce raz jeszcze ujrzeć swój twór i po latach przyznać się do niego, włożyć w cykl na tyle mocny, że sprytni krytycy nie zamienią go na „cyklinowanie”. Po drugie czekam, aż publikujący notatki z notatek krytyk, w tym profesjonalny, zechce opatrzyć swą publikację przypisem do książki polonisty, w którego seminarium kiedyś uczestniczył i głośno powie, że ten polonista nie był tchórzem, gdy używał słów o tradycji, prawdzie, wartości.

Nie będę zatem narzekać na incydenty, np. że jakiś wybitny i honorowany poeta w bodaj pięć lat od debiutu zdążył już wydać poezje 
zebrane, bo taki pośpiech obciąża jego (nie moją) biografię. Nie będę też rozwodzić się nad tym, że tzw. pisarze i tzw. krytycy „znakomitą diagnozę człowieka współczesnego" co rok wkładają w kolejną sztancę metodologiczną, bo taki proceder będzie im (nie mnie) policzony do summy zasług dydaktycznych. Do kanonu wybiorę - po prostu - i z Honeta, i ze Szlosarka, Świetlickiego czy Polkowskiego to, czym mnie, przecież także współczesną, zaskoczyli, gdy znaleźli poszerzający i przekraczający sposób wymówienia świata. Świat jak zawsze - jest dla jednostki niełaskawy. Nie ma jednak w świecie strasznym i raniącym (powtarzam tu samą siebie) niczego, co usprawiedliwiałoby literacką niechlujność, pośpiech, rozżalenie. I żadna z okoliczności życia czy koniunktur świadomościowych nie upoważnia, by rozważać kanoniczność póz/mitologii/ikon.

Nie cenię dziś słowa kanon. Wolę mówić o dziś wa ż n i e j s z e j literaturze, poezji; wolę mówić o utworach, które - jakoś - zostają wchłonięte, przeniesione, „zaopiekowane”. Zapewne za kilkadziesiąt lat trzeba będzie je od-czytywać i rewidować pod wpływem kolejnej nowinki (może już nieeuropejskiej?), ale na pewno nie poddadzą się sztuczkom prze-pisywania, montażu i synonimizacji, które unieważniają słowa istniejące. Utwory ważniejsze zostaną przeniesione i „zaopiekowane”, bo pamięć tych, którzy czytają (widzą więc wieloznaczność, ale nie „dowolność”), odnotuje ich siłę i udaremni pomysły manipulatorów od metodologii i norm nowoczesności/słuszności.

Dla kanonu nie ma znaczenia, czy ważność (wiarygodność, poręka, uznanie) ufundowana jest na normie klasycznej, czy czerpie z impulsu awangardowego. Kanon wszak dzieje się w skali najszerszej i ma stabilizować nieporządek synchronii. Dla kanonu ma jednak nadal znaczenie to, że autonomiczny autor naprawdę b i e r z e o d p owiedzialność z a przekaz i żeautonomiczny odbiorca naprawdę widzi w racji autorskiej analogon własnych intuicji i sytuacji - jeśli obaj opatrzą utwór tym samym przypisem, zweryfikują rzeczywistą zawartość słów i obrazów. Słowa i obrazy to także kostium, jeden $z$ wielu, ale nie może być niewygodny czy nie na miarę 
myśli i wzruszenia. Bo kanon to umowa, s w o i s ty k o n t ra k t a ks jologi c z ny, który ma przynieść korzyść poza tym/innym środowiskiem, koniunkturą, nowinką. Chodzi o korzyść niebagatelną, bo osobową, tożsamościową.

Nie uniknę jeszcze jednej staroświeckiej refleksji: poezja tematycznie korzysta z tego, co było „przed”, co dzieje się „w” i „między”, ale bytowo poezja zaczyna się i umacnia „po”: traumie, kryzysie, nudzie, obrzydzeniu, żalu, wstydzie, obnażeniu itd. Poezja, w przeciwieństwie do wierszowanej „publicystyki postaw i emocji”, nie zmieści się w cieniu miedzy rzeczami, idiomie ciszy i pantomimy. Poezja, w przeciwieństwie do wierszowania kryzysów, potrzebuje światła, głosu rzeczy świata. Kanon tym bardziej wyznaczać wypada „po” emocjach i koniunkturach, bo inaczej autora i zaprzyjaźnionego z nim krytyka czeka konfesjonał, a może i pręgierz. Ktoś powinien ustawicznie przypominać, że tak już u nas było; pozostał po tym okresie wstyd tych, którzy pisząc o literaturze i ustanawiając jej kanon współczesny, a rozciągnięty na wieki i po wieki, chcieli nadążyć za racją, którą artykułowali mędrcy od ekonomii, socjologii czy polityki, „od zera” fundujący nam nasze istnienie i samoodczucie.

Kanon to zawsze powaga, choć łatwo go znieważać i zeń szydzić. Dla mnie - najbardziej z naszych poetów - w kanonie polskiej poezji współczesnej mieści się powaga Czechowicza i Białoszewskiego. Później np. Wittlina, Lieberta, Wata, Sebyły, Iwaszkiewicza i Miłosza. Nieco „mniej” (niefortunne słowo) Różewicza czy Gajcego. Jeszcze inaczej i mniej - Wojaczka, Świrszczyńskiej, Grochowiaka. Jeszcze Krynickiego, choć nadal pisze. Nie widzę jednak żadnych możliwości, by dziś debatować o miejscu w kanonie dla Świetlickiego lub Szlosarka, bo znam ich „idiom” i wiem, że zapewne jeszcze kilka razy skręcą na manowce niepowagi aksjologicznej. Na szczęście nikt nie dał mi uprawnień do rozstrzygania o wielkim, mniejszym czy innym kanonie... Sama nie zdziałam nic i nikomu nic po moich zdaniach, bo kanon, jako kontrakt aksjologiczny, wymaga niespiesznej rozmowy. Jeśli więc miałabym postawić w kanonie współczesnej polskiej literatury 
poezję Teresy Ferenc, potrzebuję wsparcia, wspólnoty czytelników, przypisowej zgody na rzeczywistą ważność poza k o n i u n k t u rą. Moje argumenty (bo kanon ich potrzebuje!) chcę wszakże uchwycić i zapisać. Centra tych argumentów nazywam r z e cz a m i pi e r w s z y m i poezji ważnej, bo sięgającej po to, co naprawdę wa żniejsze w skrawku świata i w istnieniu między niebem i ziemią. Taka poezja uczy i zmienia - ale dla mnie oznacza to, że poezja pozbawia mnie domysłów i przekonań, czyni mnie kimś innym nie poprzez wzbogacanie, ale poprzez zubażanie, pomniejszenie, szansę na bycie sobą „sprzed” pisma.

2.

Po pierwsze: Teresa Ferenc odróżnia poetyki, te cudze i te własne, wprowadzane do kolejnych tomików i do ich autorskich reedycji. Z zapamiętanych stylów, z pierwszych recytacyjnych lekcji poezji, wyróżniała język np. Kochanowskiego, Tuwima, Leśmiana, Lechonia, Baczyńskiego, Herberta, Wojaczka, Kamieńskiej, Twardowskiego. Ceni Mieczysława Jastruna. Z najnowszych - Zagajewskiego. Przy czym w początkach twórczości wybierała ich wiersze tak, by pasowały do ,jej głosu”. Czy zatem o wartości jej własnego utworu, o gramatyce i stylu własnych cykli i tomików decydowały intuicja, emocje i empatia? Zapewne, bo domeną poezji jest i będzie prywatność i subiektywizm. Niektórzy sprowadzają ją do uczuciowości, inni do poetyki bądź metajęzyka. U Ferenc jest przede wszystkim od ró ż n i o ną o d r ę bn o ści ą w y o b r a ź n i. A wyobraźnia jest rzeczą pierwszą poezji. Każdej poezji, tyle że podziały na „ośmieloną" i „kamienną”, mimetyczną i retoryczną proponuję zastąpić pytaniem o wyobraźniową wiarygodność, o skuteczność jej funkcji metafizycznych i ontologicznych.

Po drugie: w przypadku Ferenc najmocniej na praktyce pisarskiej zaważył a u t e n t y k: p a m i ęć w y d a r z e ń, będąca kolejną rzeczą pierwszą każdej poezji. Poezja miała moc, by im się przeciwstawić, gdy były złem, którego nie sposób było pojąć i przeżyć/przetrwać. Miała też moc je wesprzeć, gdy były dobrem i mogły być „przeżyte”, czyli dalej istniejące. Mogła dać zranionej jednostce więcej, bo złączyła dziedziny sztuki i języki, a nade wszystko przyniosła rzeczywistą 
korzyść w autentycznym życiu. Uczyniła wypalony i rozstrzelany świat zamojskiej doliny możliwym do zamieszkania.

Po trzecie: nie mam wątpliwości, że Ferenc należy do poetów, którzy bardzo powa żnie i nie obojętnie traktują pisanie wierszy. I właśnie dlatego mówi o ich uprawianiu, plewieniu, pielęgnowaniu, wydłubywaniu. Bo poezja - każda! - wymaga s t a r a n n e g o trudu, niczym poletko i pole musi być doglądana, by dała plon. Upływ czasu, zdarzenia życia oduczają obojętności. Poezja ma środki, by nieobojętność zapisać i pokazać. W rozmowie z Henryką Dobosz, zamieszczoną w Ogniopisie, najpełniejszym autorskim wyborze wierszy, Ferenc mówi o znaczącej nieobecności niektórych spraw biografii, dla których - jeszcze - nie znalazła formy. Mówi też o domykanych kręgach, ramach tematycznych i językowych poezji wykuwanej z jednej bryły. Oraz o tym, że jej wiersze jakoś wyprzedzają świadomość. Są następstwem życia, ale zarazem są tajemniczym, bo „ustrukturalizowanym” porządkowaniem wielości jego zdarzeń. Nie muszą być religijne, by mieć siłę i sens modlitwy. Nie muszą być metafizyczne, by oznajmiać istniejący świat i jego mówiące byty.

Po czwarte: charakteryzująca tę poezję t r wałość motywów, obrazów i fraz to jedna $\mathrm{z}$ najznakomitszych metod ujarzmienia małej i wielkiej pamięci. Kolejną metodą jest $\mathrm{d}$ b a ł o ś ć o detale, o smak i zapach „bryły” codzienności. Jeszcze inną jest s c a la n i e mocnych utworów w jeszcze mocniejsze cykle trenów, psalmów, erotyków. Żaden pojedynczy wiersz Ferenc, otwierający nową tematykę i stylistykę, nie jest przecież reakcją przypadkową czy doraźną. Żaden wiersz, w chwili gdy przeniesiony zostanie do nowego tomiku, nie zostanie przenicowany czy zanegowany. Przeczytane w całości utwory, które przez dzisiejsze koniunktury chcą być zbójecko przyporządkowane nowym atrakcjom (np. traumy, postpamięci), ujawnią, że poezja po Zagładzie nie musi celebrować pustki zbędnych pytań, skoro i ona jest wiedzą. I źródłem wiedzy. Jest światłem. Wyrazem. Uczy. Nie powinna ranić. I tylko wtedy poezja jest prawdą.

Po piąte: jest to poezja k o m ple t n a, w której tzw. treść i tzw. forma sczepiają się w u ś c i s k s z t u k i. „Treść posypana popiołem”, „treść przepalająca słowa” - jest tu wszystko, co powinien dostrzec 
czytelnik wierszy Ferenc. Czytając, może podążać za biografią poetki do ostatniego dnia mieszkańców zamojskiej wsi i skonstatować unicestwienie świata. Ja wszakże widzę nieco inny sens tych słów. Jeżeli treść to ciężar strasznych wspomnień, doświadczeń, zdarzeń, popiół byłby nie tylko kresem płomieni, ale i ocalającą mocą znaków interpunkcyjnych, figur języka, d y s t a n s u li r y c z n e g o... Od dawna, jako czytelnik, powtarzam, że prawda uczuć nie jest wystarczającą prawdą w poetyckim zdarzeniu. Emocje otwierają wiersz, ale nie w nich wiersz się ostatecznie zakotwicza i umacnia. Poezję wyprowadza się „z siebie” po to, by się za siebie wychylić i zrozumieć to, co w świecie naprawdę było i jest dalej, wcześniej, później.

Po szóste: poezja po Zagładzie nie wypiera się swej istotowej powinności. Przeżycie i doświadczenie to słowa, które odnoszą się do tego, co „przeżyte” i co „przeżyło”, przetrwało, nie zostanie zatarte. Poezja Ferenc zanurza się w n i e zat a r tej prawdzi e Hioba, Syracha, Pieśni nad pieśniami, Piety, Magnificat - i tylu innych zdarzeń i słów Księgi. Zarazem w tych wierszach na równi jest prawdziwa i ważna tkanka banalnych rzeczy, które tu, teraz są i mówią. To tkanka ziemi, zwłaszcza jej, pozwala w tej poezji metaforom wieczności być ciągle blisko człowieka.

Po siódme: zrozumienie spraw wielkich - zrozumienie drobin istnienia. W najlepszych utworach Ferenc nie ma między tymi powinnościami różnicy zasadniczej. Wiersze Ferenc s c a la ją powagę prostoty z powagą nad zi e m ską. Zbliżają świętą mowę do naiwnej piosenki. Jednają banalne i podręczne naczynia z tajemnicą nieskończoności, scalają uniwersalne sensy z chropowatą fakturą materii, po którą sięga garncarz. Własna osobowość, ale i własna cielesność stają się w tej poezji sposobem komunikowania się z autonomicznym światem przedmiotów, roślin, zwierząt. To one, zadomowione w skrawku naszego świata, ale i bezpiecznie zagnieżdżone w pokładach dawnych pra-istnień, mówią to, co naprawdę ważniejsze i niezniszczalne w kulturze. My, powtarza w wierszach i cyklach poetyckich Ferenc, nic nie wiemy, one - wiedzą. Nasza niewiedza, nasze ubóstwo intelektualne jest i błogosławieństwem 
kruchego życia, i wartością poezji, która sięga po świat prawdziwy i prawdziwie istniejący.

Po ósme: wiersze te pokazują, że nadal jest w świecie skrawek przestrzeni, w którym udaje się istnieć po Zagładzie, kryzysie, destrukcji. Ferenc powie: „ja się dzieję na brzegu”, „przy morzu, lesie”, w miejscu, "gdzie rodzi się życie”. „Istnienie po” nie jest interpretacyjną metaforą. To konkret, którego żadna interpretacja nie zmieni i nie zniszczy. Najważniejszymi doś wi a d c z e n i a m i / k on k reta mi będą $\mathrm{w}$ tej poezji te, które umożliwiły istnienie. Doświadczenie domu, drzew, matki, czułości - każde z nich odnosi Ferenc do ściśle określonego czasu, miejsca. Ocalony skrawek świata, pierwsze i ostatnie miejsce na mapie życia i mapie poezji, nie pokona starości i śmierci, ale poświadcza siłę miłości, siłę wybaczenia. To wartość, z której i w naszych marnych czasach poeta nie ma mocy rezygnować.

Po dziewiąte: poezja Ferenc nie znosi pustki, nie celebruje „żadnego świata”. Nie wystarczy też napisać, że wierszom Ferenc dała siłę pamięć i trauma, wypełniające pustkę i z nią synonimiczne. Trzeba kontynuować myśl: w tej poezji pamięć zdarzeń i rzeczy sięgnęła w to, co ciągle konkretne i piękne, co dostępne poprzez $\mathrm{z}$ a u fa $\mathrm{n}$ i e do własnej źrenicy i własnej dłoni. To, czego się nie dotknęło źrenicą i palcami, nie będzie pamiętane, nie będzie niczym więcej niż niewartą poezji luką w istnieniu.

\section{3.}

Wiersze Ferenc - w tym te, które muszą wejść do kanonu polskiej liryki XX- i XXI-wiecznej (Dzikie madonny, Wiśnio wisieneczko, Matka w jesionowych drzewach, Psalm z Maria, Psalm o starych kobietach, [Poezja jak wzrok Boga...], Sochy, Psalm o tej która ocalała, Ucieczka Izaaka 1943, Matka w skrzydłach ołtarza) - nie są kolekcjonowaniem oczywistych słów o codziennych przedmiotach, ale i nie są rejestrem konceptów metaforyczno-gatunkowych. Poezji Ferenc nie ogranicza też tzw. dykcja kobieca; ma ona natomiast rolę w uwyraźnianiu autentyzmu doświadczeń jako tworzywa ekspresji poetyckiej. Poetka z przeżytej i zrozumianej prawdy zdarzeń wyprowadza prawdę poetyckich słów. Obrazy, ale i pojedyncze słowa w tej poezji 
nie są przypadkowe. Gdy bólu było za wiele, słowa wierszy dopalały zamojską dolinę. Niekiedy, zwłaszcza w ostatnich utworach Ferenc, oświetlają ją blaskiem wybaczenia i spokoju.

Najważniejszą postawę, jaką winien jest człowiek swojemu istnieniu wśród innych, nazywa Ferenc najmocniejszym słowem poezji: miłością, która nie jest synonimem miłosierdzia. $Z$ „nowych miłości” do świata, ludzi, drzew, rzeczy wynika postawa rozmowy - z mężem, z ziemią, wodą, powietrzem, ogniem, matką i Bogiem. Rozmowa zmienia te wiersze w piosenki, modlitwy, psalmy, treny, elegie lub lamentacje. Nie są kontaminacją mitologii tzw. nowoczesności, i właśnie dlatego chcę je przeciwstawić preferowanym dziś stylizacjom. Jazgotowi i nudzie przeciwstawiam więc - po poezji Ferenc - głos; milczeniu - słowa, cykle i gatunki; nieważności - powagę tego, co zapamiętywane, bo wywiedzione przez poetę z jego pamięci i co przeniesione w moją pamięć.

\section{Summary \\ The Gravity of the Canon and a Proposal from Distance (Teresa Ferenc)}

The article, in the first part, brings forward a proposal for the understanding of the canon as an axiological contract in which a given work reveals its true importance and validity aside from methodological and world-view conjunctures. In the second part, the author situates poetic works of Teresa Ferenc within the sphere of importance. The article uses concepts such as appreciation, gravity, merger, affirmation, good, importance, distinction, reduction taken from the hermeneutics of Ricoeur and Gadamer.

Małgorzata Łukaszuk (Katolicki Uniwersytet Lubelski Jana Pawła II) - dr hab., kierownik Katedry Krytyki Literackiej KUL; autorka książek: «...i w kołysankę już przemieniony płacz...». Obiit... Natus est w poezji Aleksandra Wata (Londyn 1989), «niby ja». O poezji Mirona Białoszewskiego (Lublin 1997), «Wizje splątane $z$ historiami». Autobiografia liryczna poety (Lublin 200o); wkrótce ukaże się jej książka Doświadczenie i heremeneutyka. Prace o polskiej poezji nienowoczesnej (Warszawa-Lublin 2016); redaktor pisma „Colloquia Litteraria” (UKSW), redaktor nacz. serii wydawniczej „Pisane, czytane” (KUL). 